\title{
ПУБАІЧНЕ УПРАВАIННЯ
}

\author{
DOI https://doi.org/10.32782/2305-9389/2020.22.15 \\ УДК 343.37:004.9
}

\author{
Гнатенко Валерій, \\ кандидат економічних наук, \\ науковий співробітник \\ Науково-практичного медичного \\ реабілітаційно-діагностичного иентру \\ Міністерства охорони здоров'я України
}

\section{ЗАСТОСУВАННЯ ІНФОРМАЦИЙНО-КОМУНІКАЦІЙНИХ ТЕХНОЛОГІЙ У ЗАБЕЗПЕЧЕННІ ЕКОНОМІЧНОЇ БЕЗПЕКИ ДЕРЖАВИ}

\begin{abstract}
Економічна та інформаційна глобалізачія світових відносин супроводжується створенням ефективних механізмів $i$ засобів для інформаційного та фінансового впливу на партнерів $і$ конкурентів у локальному, регіональному і глобальному масштабах. Метою таких дій, як правило, є зміна розподілу вироблених реальних благ на користь тих, хто розробляє, має $і$ застосовує відповідні технології. Ситуачія, щзо склалася, вимагає підвищення уваги до захисту державних інтересів від нових реальних $i$ потениійних загроз, забезпечення інформачійної та економічної безпеки.

Пережитий світом черговий етап технологічної революиії в інформачійній сфері тягне серйозні зміни в суспільстві у иілому. Змінюється спосіб життя мільйонів людей. Прочеси глобалізації зачіпають усе нові й нові сфери діяльності. Це стає актуальним й у сфері забезпечення національної безпеки, де чітко виділяється специффіка забезпечення інформаціийнӧ безпеки.

Загрози економічній та інформаџійній безпеиі дуже різноманітні, не завжди їх можна класифікувати й систематизувати, оскільки динаміка розвитку суспільства та економіки постійно змінюють існуючі $і$ створюють нові загрози. До таких загроз можна віднести міжнародний кібертероризм, інформаційно-фінансові атаки та ін. Тяжкість наслідків реалізаџії економічних загроз залежить не тільки від сили джерела загроз, які прагнуть змінити стан держави, а й від непідготовленості державних систем до відбиття цих загроз.

У сучасних нестійких турбулентних умовах, у світлі загострення проблеми взаємозв'язку інформачійної та економічної безпеки дуже важливо своєчасно виявляти й очінювати виникаючі загрози економічній та інформаційній безпеці $і$ на цій основі вживати необхідні заходи щзодо запобігання загрозам, захисту інформаційних і економічних інтересів від потенційних джерел небезпеки.
\end{abstract}

Ключові слова: безпека, національна безпека, інформаційна безпека, інформаційна війна, інформаційні технологї.

\footnotetext{
Hnatenko Valeriy. The use of information and communication technologies in ensuring of the state economic security

Economic and informative globalization of world relations is accompanied by the creation of effective mechanisms and means for information and financial influence on partners and competitors at the local, regional and global scales. The purpose of such actions, as a rule, is to change the distribution of produced real goods in favor of those who develop, have and apply appropriate technologies. The current situation requires raising the profile of the protection of state interests from new real and potential threats, provision of information and economic security.

By-gone stage of the technological revolution in the information sphere experienced by the world hobbles along serious changes in the society as a whole. The way of life of millions of people is changing. The processes of globalization affect more and more areas of activity. This is becoming relevant in the field of national security. In this area, the specifics of information security are clearly distinguished.

Threats to economic and information security are very different, they cannot always be classified and systematized, because the dynamics of society and economy development constantly changes existing ones and creates new threats. Such threats include international cyber terrorism, information and financial attacks and others. The severity of the consequences of the implementation of economic threats depends not only on the strength of the source of threats that try to change the state position, but also on the unpreparedness of state systems to strike these threats.

In modern unstable turbulent environment, in light of the aggravating a problem of information and economic security, it is very important to identify and assess emerging threats to economic and information security timely, and on this basis to initiate necessary measures to prevent threats, to protect information and economic interests from potential sources of danger.
}

Key words: safety, national security, information security, information war, information technologies. 
Постановка наукової проблеми та її значення. Нові реалії сучасності турбулентного світу вимагають нового підходу до питань забезпечення економічної безпеки, в якій дедалі важливішу роль починають грати інформаційно-комунікаційні технології та інформаційна безпека. Такі тенденції інтенсивно розвиваються з 80 -х років минулого століття і викликані науково-технічним прогресом у сфері інформаційних технологій, глобальних систем телекомунікацій, засобів зв'язку. У зазначеному періоді виникли ефективні технічні засоби цифрового інформаційного обміну, які могли забезпечувати інформаційно-комунікаційне 3'єднання різних районів світу в глобальну економічну систему.

Для сучасного світу й окремо взятих держав небезпека інформаційних загроз постійно зростає, оскільки сьогодні основні «війни» та «атаки» починаються і розвиваються в інформаційному просторі. Відповідно, завоювання цього простору багато в чому визначає результат тих чи інших протистоянь між державами, товариствами, народами, регіонами, соціальними групами, що здійснюють свою діяльність у суспільстві.

У сучасних умовах розвитку світових глобальних інформаційно-комунікаційних систем і глобалізації економічних відносин проблема забезпечення економічної безпеки соціальних систем, що володіють державним суверенітетом, набуває нового змісту і нового значення: система забезпечення економічної безпеки за своєю суттю покликана служити гарантом суверенітету і незалежності країни, ії̈ стабільного та стійкого соціально-економічного розвитку, оскільки національна безпека і обороноздатність країни тісно пов'язані зі станом економіки.

Ці питання в різних аспектах розглянуто у працях як вітчизняних, так і зарубіжних дослідників: Д. Белла, Е. Гіденса, М. Кастельса, Д. Лайона, У. Мартіна [1], В.Б. Бритко, С.В. Дубовського [2], М.К. Горшкова [3], О.Д. Довганя, Т.Ю. Ткачук [4], Є.Г. Дьякової [5], А.Ю. Нашінець-Наумової [6], I.М. Панаріна [7], О.А. Панченко [8-14], Г.А. Сатарова [15], А.І. Соловйової [16], В.М. Торяник [17], Я.І. Чмир [18] та ін.

В умовах модернізації економічного, політичного і соціального устрою сучасного суспільства, перетворення всіх державних і громадських інститутів на тлі динамічних процесів, що відбуваються у світі, проблема забезпечення національної безпеки держави в інформаційній сфері набула особливої гостроти.

Мета статті - провести аналітичний огляд чинників і аспектів впливу інформаційно-комунікаційних технологій на економічну та інформаційну безпеку в системі забезпечення національної безпеки.

Виклад основного матеріалу й обгрунтування отриманих результатів дослідження. Розвиток військової техніки і технологій призвів до практичного унеможливлення ведення війни у великих масштабах. Основною зброєю в XXI ст. усе більшою мірою стають економічні, передусім фінансові, методи. Багато країн світу не мають свого конкурентоспроможного науково-технічного потенціалу та повністю залежать від техніки і технології розвинених країн. Країни, що розвиваються, а в перехідний період до них стала належати й Україна, залежать від політики міжнародних фінансових організацій: Міжнародного валютного фонду (МВФ), Світового банку, Міжнародного банку реконструкції та розвитку (МБРР) тощо. Ці організації були створені в кінці Першої світової війни для досягнення переваги над соціалістичною системою у фінансовій сфері і через це - в економічній сфері. Практика 90-х років минулого століття і нульових років нинішнього століття показала високу ефективність інформаційно-фінансового впливу на національну економіку, що дає змогу вирішувати політичні завдання без ведення бойових дій.

Сучасний соціально-економічний розвиток держави нерозривно пов'язаний із загостренням проблеми забезпечення її економічної безпеки, розширенням масштабів економічних загроз і появою нових форм і видів економічної злочинності. У контексті даного питання до ризиків національної безпеки можна віднести і блок інформаційних загроз, оскільки інформаційна сфера $є$ фактором прогресу, одночасно виступає й як специфічний носій загроз економічній безпеці країни.

У сучасних умовах інформаційні впливи на економічні процеси, включаючи фінансову сферу, стають усе більш агресивними. Так, наприклад, колосальний економічний збиток може виникати i, безумовно, виникає за впливу негативної інформації на фондові ринки, а через них - на зниження капіталізації підприємств, які можуть скуповуватися недобросовісними економічними суб' єктами або навіть злочинцями за низькою ціною.

Сучасний етап розвитку суспільства характеризується зростаючою роллю інформаційної сфери, що являє собою сукупність інформації. Інформаційна сфера є системоутворюючим чинником життя суспільства, активно впливає на стан політичного, економічного, оборонного та інших складників національної безпеки. Під інформаційною безпекою держави розуміється стан захищеності ії національних інтересів в інформаційній сфері, що визначаються сукупністю збалансованих інтересів особистості, суспільства і держави [8, с. 59]. 
Новий виток технологічних успіхів інформаційно-комунікаційних технологій поряд із прогресивними можливостями породжує й нові загрози безпеці. За роки незалежності кардинально змінилися форми власності, багаторазово розширився ідеологічний спектр політичних партій і рухів, загострилася соціальна диференціація суспільства, трансформуються уявлення про роль і місце нашої держави в новому мінливому світі. Поряд із тим, що в більшості сфер діяльності держави відбуваються позитивні зміни в реалізації реформ, необхідно підкреслити, що розвиток інформаційної сфери країни об’єктивно переживає складний період, ії ресурси, у тому числі й їх захищеність, відстають у розвитку від інших інститутів сучасного суспільства.

Важливим інформаційним складником системи забезпечення національної безпеки $є$ інформаційнокомунікаційні технології, а також технічні, програмні, лінгвістичні, правові, організаційні засоби, включаючи телекомунікаційні канали, які повинні бути застосовані в системі забезпечення національної безпеки для збору, формування, обробки, передачі або прийому інформації про стан національної безпеки і заходи щодо ії зміцнення, і тим самим утворюють засоби забезпечення національної безпеки. Сили і засоби забезпечення національної безпеки зосереджують свої зусилля і ресурси на забезпеченні національної безпеки у внутрішньополітичній, економічній, соціальній сферах, у сфері науки і освіти, в міжнародній, духовній, інформаційній, військовій, оборонно-промисловій та екологічній сферах, а також у сфері громадської безпеки.

Найважливішу роль у забезпеченні інформаційної безпеки, безсумнівно, грає ії захищеність, створювана державою за допомогою низки заходів і покликана протистояти реальним і потенційним загрозам національній безпеці як ззовні, так і зсередини країни.

Самостійний блок інформаційних загроз являє прагнення окремих країн до домінування у світовому інформаційному просторі. Так, наприклад, нині близько $70 \%$ усіх комунікаторів світу належать протиборчим між собою американським і російським корпораціям. Інформаційна сфера стає не лише найважливішою сферою міжнародної співпраці, а й об'єктом суперництва. Проблеми у сфері інформаційних відносин, формування інформаційних ресурсів та користування ними загострюються внаслідок політичного й економічного протиборства різних держав, що має місце в інформаційній нерівності. При цьому ведеться активна робота з витіснення неугодних держав із зовнішнього і внутрішнього інформаційних ринків, залучення країн у так звані «інформаційні війни» 3 метою порушення нормального функціонування інформаційних та телекомунікаційних систем, а також збереження інформаційних ресурсів. На тлі всього цього спостерігається й тенденція отримання несанкціонованого доступу з боку іноземних спецслужб та інших осіб до інформації економічного характеру і використання ії з метою підриву економічної безпеки держави.

Реалізація національних інтересів держави можлива тільки на основі сталого розвитку економіки та забезпечення іiї безпеки в інформаційній сфері. Проблема сталого розвитку країни не $\epsilon$ новою, подібного роду проблеми постійно обговорюються у світі, зокрема вони обговорювалися на Пленарному засіданні 42-ї сесії Генеральної Асамблеї ООН (20 жовтня 1987 р.), на якому були прийняті принципи, що розкривають сутність сталого розвитку. В основу зазначених принципів було закладено задоволення потреб сучасного покоління, не загрожуючи можливості майбутніх поколінь задовольняти власні потреби, тобто принципи взаємозв'язку економічного і соціального розвитку за раціонального використання ресурсів і захисту навколишнього середовища. У 1992 р. на конференції в Ріо-де-Жанейро зазначені принципи сталого розвитку були прийняті главами урядів понад 150 країн.

Із 1999 р. на міжнародних конференціях під егідою ООН ведуться дискусії щодо визначення змісту сталого розвитку країн. У всіх подібних дискусіях забезпечення економічної безпеки $є$ центральною ланкою національної безпеки і найважливішою умовою сталого розвитку держави.

В умовах глобалізації світового господарства фінансова безпека як ключовий складник економічної безпеки країни $€$ першорядною. У світлі цього підвищується роль інформації і розвитку телекомунікацій як основи взаємодії фінансових і фондових ринків. У сучасних умовах загострення проблеми обмеження природних ресурсів питання економічної і, як наслідок, інформаційної безпеки стають не менш важливими, ніж питання військової безпеки. У сучасних умовах виявилося, що війна в традиційному розумінні, з веденням бойових дій за можливість захоплення й утримання території, $\epsilon$ далеко не єдиною загрозою безпеці. Основним чинником впливу в навколишньому світі стає економічний вплив через фінансові інструменти. Інформаційний вплив застосовується як для забезпечення застосування фінансових інструментів, наприклад під час атак на валютних і фондових ринках, так і як ідеологічне прикриття під час створення необхідного образу справедливості проведеної політики в суспільній свідомості. 
Загрози економічній та інформаційній безпеці стосуються не лише окремих компонентів державної системи, а й регіонів, великих господарюючих суб'єктів і територіальних утворень, вони формують соціально-інформаційний вплив на соціально-економічну систему держави.

Інформаційні системи, що включають телекомунікації, аналітичну та прогнозовану інформацію, впливають не лише на стан ринку цінних паперів, а й на стан фінансової системи країни у цілому. У результаті таких дій відбуваються коливання курсів національних валют, зміна цін і зниження конкурентоспроможності товарів і послуг, створюються загрози економічній безпеці суб’єктів ринку держави.

Рішення завдань забезпечення безпеки в інформаційній сфері не зводяться лише до захисту каналів і засобів передачі інформації, охорони державної таємниці, урядового зв'язку та інформації та інших питань, які прийнято розглядати під час аналізу сукупності загроз і системи заходів щодо забезпечення інформаційної безпеки. До питань інформаційної безпеки в економічній сфері також належить безпека інформаційних систем управління промисловістю, галузями, підприємствами, банками.

Економічні та інформаційні загрози можуть виникати щодо будь-якого елементу економічної системи країни або зв'язків між ними, у тому числі щодо потоків товарів і послуг, грошових потоків, інформаційних потоків. Окрім того, загрози безпеці можуть виникати щодо тих елементів економічної системи або їх зв'язків, які можуть з'явитися в майбутньому, але визначити зміст яких на разі не представляється можливим.

Загрози економічній та інформаційній безпеці можуть бути спрямовані як на руйнування будь-якого компонента системи забезпечення національної безпеки та їх взаємозв'язку, так і на механізм забезпечення у цілому.

Інформаційні загрози економічній безпеці мають різний характер, закінчуються у системах зв'язку і телекомунікацій, можуть бути глобальними за своїми масштабами (такі прийнято називати викликами), регіональними, тобто відносяться до певного регіону, групі країн, або загрози національні, що виникають у самій країні.

У сучасних нестабільних і турбулентних умовах економічні загрози, як правило, мають довгостроковий характер і спрямовані на руйнування економічного потенціалу країни, іiі життєзабезпечуючих сфер. Вплив загроз в інформаційній сфері все більше спрямований на інтереси особистості, суспільства і держави. При цьому вплив на особистість із метою зниження активності життєвої позиції все більше здійснюється за допомогою комунікаційних засобів і технологій. При цьому неухильно зростає інформаційний вплив на економічну систему, включаючи іiі фінансову сферу, фондові ринки з грою на пониження капіталізації підприємств, а потім їх скуповуванням за нижчою ціною, у поєднанні з поширенням інформації щодо створення негативного образу конкурента тощо.

Висновки та перспективи подальших досліджень. Нові виклики і загрози (перш за все міжнародний кібертероризм, інформаційне шпигунство, організована злочинність в інформаційній сфері, небезпека поширення вірусних комп'ютерних атак на інформаційно-керуючі системи в економіці та, перш за все у фінансовій сфері, і т. д.) носять глобальний характер і вимагають адекватної відповіді з боку всього міжнародного співтовариства та солідарних зусиль для їх подолання.

Нині істотно зростає роль інформаційної безпеки національної економіки, все більш актуальною стає проблема боротьби з кіберзлочинністю у фінансовій сфері. Верховною Радою України було зроблено спробу врегулювати відносини, що виникають у кіберпросторі, а саме ухвалено Закон України «Про основні засади забезпечення кібербезпеки в Україні». Незважаючи на ці кроки, Україна постійно стає жертвою кібератак.

На забезпечення національних інтересів держави негативний вплив можуть чинити ймовірні рецидиви односторонніх силових підходів у міжнародних відносинах, протиріччя між основними учасниками світової політики, а також удосконалення форм протиправної діяльності в кібернетичній та біологічній сферах, у сфері інформаційно-комунікаційних технологій.

Складність завдань, що стоять перед державою, вимагає вироблення збалансованої стратегії їх вирішення, що виходить із взаємозв'язку проблем національної безпеки, соціально-економічного розвитку країни та інформаційної безпеки національної економічної системи.

Література:

1. Мартин У.Дж., Лайон Д. Информационное общество: проблемы и иллюзии. Москва : ИНИОН, 1989, 648 с.

2. Бритков В.Б., Дубовской С.В. Информационные технологии в национальном и мировом развитии. Общественные науки и современность. 2000. № 1. С. 146-150.

3. Горшков М.К. Проблемы национальной безопасности в информационном обществе. Власть. 2014. № 11. С. 8.

4. Довгань О.Д., Ткачук Т.Ю. Система інформаційної безпеки України: онтологічні виміри. Інформаиія і право. 2018. № 1(24). С. 89-103. 
5. Дьякова Е.Г. Массовая коммуникация и власть. Екатеринбург : УрО РАН, 2002, 299 с.

6. Нашинець-Наумова А.Ю. Інформаційна безпека: питання правового регулювання : монографія. Київ : Гельветика, 2017. $168 \mathrm{c}$.

7. Панарин И.Н. Информационная война, PR и мировая политика : учебное пособие ; 3-е изд., испр. и доп. Москва : Горячая линия - Телеком, 2018. 370 с.

8. Панченко О.А. Інформаційна безпека в контексті викликів і загроз національній безпеці. Державне управління та місиеве самоврядування. 2020. Вип. 2(45). С. 57-63. DOI: 10.33287/102019. URL: https://grani-print.dp.ua/index.php/ dridu/article/view/361/286.

9. Панченко О.А. Інформаційна безпека держави як елемент соціальної культури. Аспекти публічного управління. 2020. № 1. T. 8. C. 58-67. URL: https://aspects.org.ua/index.php/journal/article/view/720/692.

10. Панченко О.А. Інформаційні аспекти трансформації державного управління в умовах турбулентності. The system of public administration in the context of decentralization of power : collective monograph. Riga : Izdevnieciba Baltija Publishing, 2020. P. 88-110. DOI: https://doi.org/10.30525/978-9934-588-66-2-06.

11. Панченко О.А. Засоби масової інформації як джерело інформаційної безпеки. Експерт: парадигми юридичних наук і державного управління. 2020. № 2(8) C. 250-258. DOI: 10.32689/2617-9660-2020-2(8)-250-258. URL: http:// maup.com.ua/assets/files/expert/8/21.pdf.

12. Панченко О.А. Засоби масової комунікації як платформа державної інформаційної політики. Державне управління: удосконалення та розвиток. 2020. № 4. DOI: 10.32702/2307-2156-2020.4.2. URL: http://www.dy.nayka.com.ua/ pdf/4_2020/4.pdf.

13. Панченко О.А. Роль засобів масової інформації в системі державного управління інформаційною безпекою. Публічне управління та митне адміністрування. 2020. № 1(24). С. 97-102. DOI: 10.32836/2310-9653-2020-1.19. URL: http:// customs-admin.umsf.in.ua/archive/2020/1/19.pdf.

14. Панченко О.А. Information technologies in ensuring of the state security. Інформаційні технології в забезпеченні державної безпеки. Science Review. 2020. Warsaw, Poland. № 5(32). June 2020. P. 30-35. DOI: https://doi.org/10.31435/ rsglobal_sr.

15. Сатаров Г.А. Общественное мнение и общественное сознание: реальность и миф. ОНС: Общественные науки и современность. 2007. № 4. С. 5-23.

16. Соловьев А.И. Политические коммуникации. Москва : Аспект Пресс, 2004, 332 с.

17. Торяник В.М. Інформаційна безпека як складова національної безпеки держави, роль ЗМІ в забезпеченні інформаційного суверенітету України. Право і суспільство. 2016. № 2. С. 151-156.

18. Чмир Я.І. Проблеми забезпечення інформаційної безпеки в системі публічного управління. Аспекти публічного правління. 2018. Т. 6. № 9. С. 16-22. 